\title{
PENGEMBANGAN MODUL E-LEARNING BERBASIS WEB DALAM PEMBELAJARAN PENDIDIKAN PANCASILA DAN KEWARGANEGARAAN PADA MAHASISWA IKIP BUDI UTOMO MALANG
}

\author{
Faizah Ulumi Firdausi, M.Pd ${ }^{1}$ \\ Faizahf89@gmail.com \\ Puspita Pebri Setiani, M.Pd ${ }^{2}$ \\ puspitapebrisetiani@budiutomomalang.ac.id \\ ${ }^{1,2}$ Prodi Pendidikan Sejarah dan Sosiologi \\ Fakultas Pendidikan Ilmu Sosial Dan Humaniora \\ IKIP Budi Utomo Malang
}

\begin{abstract}
Abstrak
Research on the development of e-learning module in learning Pendidikan Pancasila dan Kewarganegaraan has a goal where the e-learning module into an alternative web-based teaching materials that are easily accessible and used IKIP Budi Utomo Malang students. The e-learning module is web-based learning Pendidikan Pancasila dan Kewarganegaraan intended for students IKIP Budi Utomo Malang where subjects Pendidikan Pancasila dan Kewarganegaraan be compulsory subject as the formation of characters berbudiutama college students who are in harmony with the vision of campus IKIP Budi Utomo Malang that is "Became Higher Education university Education and Training excellence of superior, healthy and standard international in the year 2022 "where Berbudiutama in the vision as an effort to form a noble personality or berakhlaq noble (akhlaqul karimah). IKIP Budi Utomo Malang must carry and realize the values of usefulness, awareness, compliance, propriety and Indonesian.

Implementation of research begins with Research and information, where Research and information is used to collect information about the needs of learning materials that are easily accessible by students with the sophistication of IT. Then proceed to the ADDIE model. The result of research of the development of web-based e-learning module in learning Pendidikan Pancasila dan Kewarganegaraan to improve the character of good students of IKIP Budi Utomo Malang.
\end{abstract}

Keywords: module, e-learning, web, Pendidikan Pancasila dan Kewarganegaraan and characters berbudiutama. 


\section{PENDAHULUAN}

Salah satu tantangan
pendidikan dewasa ini adalah
membangun keterampilan abad 21,
diantaranya adalah keterampilan
melek teknologi informasi dan
komunikasi (information \&
communication technology literacy
skill). Keterampilan tersebut itulah yang menurut Perserikatan Bangsa Bangsa (PBB) merupakan ciri dari masyarakat era global saat ini, yaitu masyarakat berpengetahuan (knowledge-based scoeity) (Chaeruman, 2010). Teknologi informasi dan komunikasi (TIK), memiliki potensi yang sangat besar sebagai sarana atau alat untuk mengembangkan keterampilan tersebut dalam proses pembelajaran. Oleh karena itu, dalam pendidikan modern, dosen dituntut untuk mampu mengintegrasikan TIK dalam proses pembelajaran. TIK seharusnya tidak hanya dijadikan objek yang harus dipelajari atau memposisikan mahasiswa sebagai orang yang belajar TIK namun apa yang seharusnya terjadi adalah dalam proses pembelajaran harus menggunakan TIK sehingga mahasiswa sekaligus belajar TIK di sana (learning with or trhough ICT).

Learn Frame (dalam Glossary of eLearning Terms, 2001) menyatakan suatu definisi $e$ Learning adalah sistem pendidikan yang menggunakan aplikasi elektronik untuk mendukung belajar mengajar dengan media, dimana fungsi e-learning terhadap kegiatan pembelajaran di dalam kelas, yaitu sebagai tambahan (suplemen), pelengkap (komplemen), atau pengganti (substitusi). Dikatakan berfungsi sebagai suplemen (tambahan), apabila peserta didik mempunyai kebebasan memilih, apakah akan memanfaatkan materi $e$ learning atau tidak. Dalam hal ini, tidak ada kewajiban/keharusan bagi peserta didik untuk mengakses materi e-learning. Sebagai komplemen berarti materi e-learning diprogramkan untuk menjadi materi reinforcement (pengayaan) atau remedial bagi peserta didik di dalam mengikuti kegiatan pembelajaran konvensional. Materi e-learning juga dapat berfungsi sebagai enrichment, apabila kepada peserta didik yang dapat dengan cepat menguasai atau memahami materi pelajaran yang disampaikan guru secara tatap muka (fast learners) diberikan kesempatan untuk mengakses materi e-learning yang memang secara khusus dikembangkan untuk mereka.

Cara belajar melalui web syarat utama yang harus dipenuhi yaitu adanya akses dengan sumber informasi melalui internet. Selanjutnya adanya informasi tentang dimana letak sumber informasi yang ingin kita dapatkan. Ada beberapa sumber data yang dapat diakses dengan bebas dan gratis, tanpa proses administrasi pengaksesan yang rumit. Ada beberapa sumber informasi yang hanya diakses oleh pihak yang 
memang telah diberi otorisasi pemilik sumber informasi.

Rusman (2011) menjelaskan pembelajaran berbasis web merupakan suatu pembelajaran yang bisa diakses melalui jaringan internet. Pembelajaran berbasis web yang popular dengan sebutan webbased traning (WBT) atau kadang juga disebut web based education (WBE) dapat didefinisikan sebagai aplikasi teknologi web dalam dunia pembelajaran untuk sebuah proses pendidikan. Secara sederhana dapat dikatakan bahwa semua pembelajaran yang memanfaatkan teknologi internet dan selama proses belajar dirasakan terjadi oleh yang mengikutinya maka kegiatan itu dapat disebut sabagai pembelajaran berbasis web.

$$
\text { Matakuliah Pendidikan }
$$

Pancasila dan Kewarganegaraan adalah matakuliah khas dan wajib dari IKIP Budi Utomo Malang, dimana luaran matakuliah Pendidikan Pancasila dan Kewarganegaraan adalah karakter berbudiutama hal ini sejalan dengan visi IKIP Budi Utomo Malang, yakni "Menjadi Perguruan Tinggi Kependidikan dan Keguruan berbudiutama yang unggul, sehat dan bertaraf internasional pada tahun 2022" dimana Berbudiutama dalam visi tersebut sebagai upaya membentuk kepribadian luhur atau berakhlaq mulia (akhlaqul karimah). IKIP Budi Utomo Malang harus mengemban dan mewujudkan nilainilai yaitu kemanfaatan, kepedulian, kepatuhan, kepatutan dan KeIndonesiaan.

Melalui modul e-learning berbasis web dalam pembelajaran Pendidikan Pancasila dan Kewarganegaraan diharapkan mahasiswa mampu mengakses dengan mudah sehingga pembelajaran Pendidikan Pancasila dan Kewarganegaraan dengan mudah dapat dipelajari oleh mahasiswa IKIP Budi Utomo Malang. modul elearning berbasis web juga mampu mempermudah mengevaluasi karakter berbudi mahasiswa dari hasil pembelajaran Pendidikan Pancasila dan Kewarganegaraan, modul e-learning berbasis web pembelajaran Pendidikan Pancasila dan Kewarganegaraan dilengkapai dengan materi dan alat evaluasi karakter yang afektif untuk mahasiswa dalam hasil pembelajaran Pendidikan Pancasila dan Kewarganegaraan. Adapun tujuan dalam penelitian ini adalah :

1. Menjadikan modul e-learning berbasis web dalam pembelajaran Pendidikan Pancasila dan Kewarganegaraan sebagai bahan ajar yang mudah diakses dalam pembelajaran Pendidikan Pancasila dan Kewarganegaraan.

2. Menjadikan modul e-learning berbasis web dalam pembelajaran Pendidikan Pancasila dan Kewarganegaraan sebagai bahan ajar yang mampu meningkatkan karakter 
berbudiutama mahasiswa IKIP Budi Utomo Malang.

\section{METODE PENELITIAN}

Metode penelitian yang digunakan adalah Research And Development (Penelitian dan Pengembangan). Model pengembangan yang menjadi acuan peneliti yaitu Model Borg \& Gall dan ADDIE. Model research and development ini di kombinasikan karena di sesuaikan dengan langkahlangkah dalam proses penelitian dan pengembangan yang dilakukan oleh peneliti. Pada model Borg \& Gall langkah yang diambil adalah research and information. Research and information digunakan untuk mengumpulkan informasi tentang kebutuhan bahan ajar dalam matakuliah Pendidikan Pancasila dan Kewarganegaraan pada mahasiswa IKIP Budi Utomo Malang. Kemudian pada model ADDIE langkah-langkah yang diambil sama seperti aslinya yang mencakup aspek Analyze (analisis), Design (perancangan), Development (pengembangan), Implementation (penerapan), dan Evaluation (penilaian).

Teknik pengumpulan data menggunakan teknik observasi, angket dan dokumentasi yang kemudian dianalisis menggunakan Analisis Uji Coba Perangkat Tes. Adapun analisis perangkat tes tersebut adalah sebagai berikut :

1) Deskriptif Persentase Setelah data diperoleh, selanjutnya adalah menganalisis data tesebut.

Penelitian ini lebih menitikberatkan pada bagaimana mengembangkan modul pembelajaran sehingga data dianalisis dengan sistem deskriptif persentase.

2) Mengkuantitatifkan hasil checking sesuai dengan indikator yang telah ditetapkan dengan memberikan skor sesuai dengan bobot yang telah ditentukan sebelumnya.

3) Membuat tabulasi data.

Sedangkan untuk menganalisis data dari angket dilakukan langkah-langkah sebagai berikut:

1) Angket yang telah diisi responden, diperiksa kelengkapan jawabannya, kemudian disusun sesuai dengan kode responden.

2) Mengkuantitatifkan jawaban setiap pertanyaan dengan memberikan skor sesuai dengan bobot yang telah ditentukan sebelumnya.

3) Membuat tabulasi data.

4) Menghitung persentase dari tiap-tiap sub variable dengan rumus yang digunakan dalam perhitungan persentase skor checklist.

Selanjutnya dilakukan analis data yang digunakan pada analisis 
tahap awal adalah nilai ulangan terakhir bab sebelumnya. Analisis data awal dan akhir menggunakan Uji Normalitas dan uji Heterogentias selanjutnya dilakukan Uji t-Satu Pihak yang digunakan Untuk mengetahui bahwa hasil belajar siswa dari kelas yang diberi pembelajaran dengan menggunakan e-modul Pendidikan Pancasila dan Kewarganegaraan lebih baik, diuji dengan menggunakan uji $\mathrm{t}$ pihak kanan.

\section{HASIL DAN PEMBAHASAN}

\section{Deskripsi Hasil Tahap Analisis}

Tahap analisis digunakan untuk memperoleh informasi mengenai kebutuhan atau masalah yang mendasar melatarbelakangi dikembangkannya modul e learning berbasis web.

Setelah melakukan observasi pada mahasiswa Program Studi Pendidikan Sejarah dan Sosiologi, peneliti memperoleh informasi bahwa mahasiswa belum menggunakan e modul dalam pembelajaran Pendidikan Pancasila dan Kewarganegaraan, mahasiswa kurang tertarik terhadap materi yang disampaikan menggunakan model pembelajaran presentasi dan dirasa sangat monoton. Sesuai dengan perkembangan ilmu pengetahuan dan teknologi IKIP Budi Utomo malang mulai mendorong kepada dosen maupun mahasiswa untuk meninggalkan kertas dan beralih ke media pembelajaran berbasis e learning. Penggunaan e learning berbasis web ini akan memudahkan mahasiswa untuk memperoleh bahan ajar di mata kuliah Pendidikan Pancasila dan Kewarganegaraan karena hampir semua mahasiswa dapat mengakses dengan mudah melalui hand phone maupun warnet.

Secara umum pengembangan e modul berbasis web ini membantu mahasiswa dalam memahami materi kebudiutaamaan sehingga diharapkan mampu lebih cepat membentuk karakter berbudiutama dalam diri siswa sesuai dengan visi dan misi pendidikan yang ada dalam perguruan tinggi Budi Utomo.

\section{Deskripsi Hasil Tahap Desain}

Pada tahap desain ini, peneliti menentukan kompetensi khusus yang dicapai oleh mahasiswa, metode, bahan ajar, strategi pembelajaran serta media pembelajaran. Peneliti menggunakan modul e learning berbasis web. Dalam pengembangan perangkat media pembelajaran ini, peneliti menentukan kompetensi khusus yang harus dicapai siswa. Kompetensi khusus yang dicapai oleh siswa sebagai berikut.

1) Mahasiswa dapat mengakses modul e learning berbasis web

2) Mahasiswa dapat memahami isi modul e learning berbasis web

3) Mahasiswa dapat menggunakan modul e learning berbasis web ini sebagai bahan ajar pada 
pembelajaran

Pendidikan Pancasila

dan Kewarganegaraan

4) Mahasiswa dapat

memetik nilai karakter

berbudiutama

Metode pembelajaran yang digunakan peneliti ini adalah metode kooperatif. Bahan ajar yang digunakan peneliti adalah modul e learning berbasis web. Strategi pembelajaran yang dipilih adalah aktif learning. Metode dan strategi pembelajaran dipilih sesuai dengan karakteristik bahan ajar modul e learning berbasis Web yaitu konstruktivisme.

\section{Deskripsi Hasil Pengembangan}

Pada tahap pengembangan peneliti (1) membuat rancangan perangkat pembelajaran berupa SAP, media pembelajaran dan buku ajar, (2) memvalidasi perangkat pembelajaran kepada validator. Berikut uraian singkat perangkat pembelajaran dan hasil perangkat pembelajaran.

1) Rancangan Perangkat Pembelajaran

Rancangan perangkat pembelajaran yang dimaksud peneliti adalah seluruh kegiatan membuat dan memodifikasi perangkat pembelajaran berupa SAP, modul e learning berbasis web dan buku ajar. Berikut uraian singkat rancangan perangkat pembelajaran meliputi SAP, modul e learning berbasis web.

1) SAP

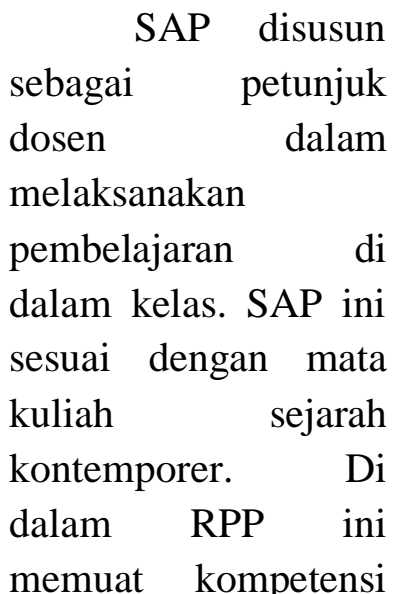
inti, kompetensi dasar, indikator pencapaian kompetensi, tujuan pembelajaran, uraian materi, model/metode, media, alat pembelajaran yang digunakan, kegiatan pembelajaran, alokasi waktu, dan penilaian autentik.

2) Modul e learning Sesuai dengan sub materi yang dipilih dan rancangan SAP, maka modul e learning pembelajaran dipilih sesuai materi untuk 3 kali pertemuan. Desain modul e learning diatas dipilih semenarik mungkin agar mahasiswa termotivasi dalam mengikuti kegiatan pembelajaran dan mempermudah 
mahasiswa dalam proses kegiatan pembelajaran.

\section{Hasil Validasi Produk}

Dalam penelitian ini, proses validasi dilaksanakan selama 1 minggu dengan validator yang berkompeten dan mengerti tentang isi materi, desain pembelajaran, dan media pembelajaran.

Tabel 1. Daftar Nama Validator

\begin{tabular}{|c|l|l|}
\hline No & \multicolumn{1}{|c|}{$\begin{array}{c}\text { Nama } \\
\text { Validator }\end{array}$} & $\begin{array}{l}\text { Keterangan } \\
1\end{array}$ \\
\hline $\begin{array}{l}\text { Dra. Amanah } \\
\text { Agustin, } \\
\text { M.Pd }\end{array}$ & $\begin{array}{l}\text { Dosen } \\
\text { Pendidikan } \\
\text { Sejarah dan } \\
\text { Sosiologi } \\
\text { IKIP Budi } \\
\text { Utomo } \\
\text { Malang }\end{array}$ \\
\hline 2 & $\begin{array}{l}\text { Dr. Nasution, } \\
\text { M.Ed, Ph. D }\end{array}$ & $\begin{array}{l}\text { Dosen } \\
\text { Pendidikan } \\
\text { Sejarah dan } \\
\text { Pasca } \\
\text { Sarjana } \\
\text { UNESA }\end{array}$ \\
\hline
\end{tabular}

Hasil dari validasi perangkat sebagai berikut

1) Validasi isi mata kuliah

Penilaian validator terhadap isi mata kuliah meliputi beberapa aspek yaitu kejelasan indikator, kejelasan indikator dengan materi, kejelasan tujuan pembelajaran, kejelasan materi dan tujuan dll. Hasil penilaian secara singkat disajikan dalam tabel 2 sebagai berikut:

Tabel 2. Hasil Validasi Isi Mata Kuliah

\begin{tabular}{|c|l|c|}
\hline No & \multicolumn{1}{|c|}{ Kriteria } & $\begin{array}{c}\text { Skor } \\
\text { Nilai }\end{array}$ \\
\hline 1 & $\begin{array}{l}\text { Kejelasan } \\
\text { indikator }\end{array}$ & 5 \\
\hline 2 & $\begin{array}{l}\text { Kejelasan } \\
\text { indikator } \\
\text { dengan materi }\end{array}$ & 5 \\
\hline 3 & $\begin{array}{l}\text { Kejelasan } \\
\text { tujuan } \\
\text { pembelajaran }\end{array}$ & 5 \\
\hline 4 & $\begin{array}{l}\text { Kejelasan } \\
\text { materi dengan } \\
\text { tujuan }\end{array}$ & 5 \\
\hline 5 & $\begin{array}{l}\text { Kejelasan } \\
\text { penyajian } \\
\text { materi }\end{array}$ & 4 \\
\hline 6 & $\begin{array}{l}\text { Kelengkapan } \\
\text { materi }\end{array}$ & 5 \\
\hline 7 & $\begin{array}{l}\text { Kesesuaian } \\
\text { konsep materi } \\
\text { pelajaran }\end{array}$ & $\begin{array}{l}\text { Total } \\
\text { Kesesuaian } \\
\text { evaluasi dan } \\
\text { tujuan }\end{array}$ \\
\hline 9 & $\begin{array}{l}\text { Kejelasan } \\
\text { soal/tes }\end{array}$ \\
\hline 10 & $\begin{array}{l}\text { Kesesuaian isi } \\
\text { mata pelajaran } \\
\text { dengan waktu } \\
\text { yang } \\
\text { disediakan }\end{array}$ & 4 \\
\hline & 5 \\
\hline
\end{tabular}

Berdasarkan penilaian ahli mata kuliah Pendidikan 
Pancasila

dan

Kewarganegaraan

sebagaimana

tercantum

dalam tabel 2. maka dapat

dihitung persentase tingkat pencapaian Modul e Learning berbasis Web mata Kuliah Pendidikan Pancasila dan Kewarganegaraan mahasiswa angkatan 2014 semester 5 yaitu sebagai berikut:

Persentase $=$

$\frac{E \text { (jawaban x bobot tiap pilihan) }}{\text { nx bobot tertinggi }} \times 100 \%$
$=46 /(10 \times 5) \times$
$100 \%$
$=46 / 50 \quad \mathrm{x}$

$100 \%$

$$
=92 \%
$$

Persentase pencapaian

Modul E learning berbasis Web adalah 92\%, berarti Modul E learning berbasis Web ini berada pada kategori sangat baik, sehingga Modul E learning berbasis Web tidak perlu direvisi. Namum, ahli isi mata kuliah juga memberikan saran agar materi dikembangkan lagi dan ditambah lagi guna pengembangan pada materimateri yang lainnya.

2) Validasi Desain Pembelajaran Penilaian validator terhadap desain pembelajaran meliputi beberapa aspek yaitu kemenarikan tampilan fisik Modul E learning berbasis Web, keseimbangan tata warna, kejelasan petunjuk penggunaan Modul $\mathrm{E}$ learning berbasis Web, ketepatan penggunaan desain penyajian materi dll. Hasil penilaian secara singkat disajikan dalam tabel 3 sebagai berikut

\section{Tabel 3. Hasil Validasi Desain}

\section{Pembelajaran}

\begin{tabular}{|c|c|c|}
\hline No & Kriteria & $\begin{array}{l}\text { Skor/ } \\
\text { nilai }\end{array}$ \\
\hline 1 & $\begin{array}{l}\text { Kemenarikan tampilan fisik } \\
\text { Modul E learning berbasis } \\
\text { Web }\end{array}$ & 5 \\
\hline 2 & Keseimbangan tata warna & 4 \\
\hline 3 & \begin{tabular}{lr} 
Kejelasan & \multicolumn{2}{c}{ petunjuk } \\
penggunaan Modul E \\
learning berbasis Web
\end{tabular} & 5 \\
\hline 4 & $\begin{array}{l}\text { Ketepatan penggunaan desain } \\
\text { penyajian materi }\end{array}$ & 4 \\
\hline 5 & Kejelasan paparan materi & 4 \\
\hline 6 & Kesesuaian alur cerita & 4 \\
\hline 7 & Kesesuaian teks cerita dengan & 4 \\
\hline 8 & $\begin{array}{l}\text { Kesesuaian durasi waktu dan } \\
\text { karakteristik sasaran }\end{array}$ & 4 \\
\hline 9 & $\begin{array}{l}\text { Kesesuaian penempatan } \\
\text { bagian-bagian pada Modul E } \\
\text { learning berbasis Web }\end{array}$ & 5 \\
\hline 10 & $\begin{array}{l}\text { Keseuaian evaluasi dan } \\
\text { tujuan }\end{array}$ & 5 \\
\hline \multicolumn{2}{|c|}{ Jumlah } & 44 \\
\hline
\end{tabular}

Berdasarkan penilaian

dari ahli desain pembelajaran 
sebagaimana tercantum

dalam tabel di atas maka dapat dihitung persentase tingkat pencapaian Modul E learning berbasis Web yaitu sebagai berikut:

Persentase $=$

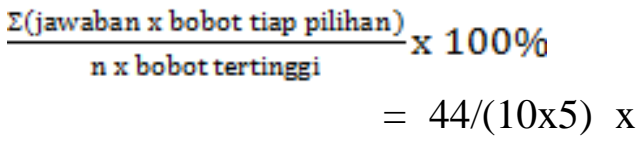

$100 \%$

$$
=46 / 50 \mathrm{x}
$$

$100 \%$

$$
=88 \%
$$

Persentase pencapaian Modul E learning berbasis Web adalah $88 \%$. Ini berarti, Modul E learning berbasis Web ini berada pada kategori baik sehingga Modul E learning berbasis Web tidak perlu direvisi.

3) Validasi Modul e learning Penilaian validator terhadap modul pembelajaran meliputi beberapa aspek yaitu kesesuaian modul dengan tujuan, kesesuaian modul dengan peserta didik, kejelasan tampilan Modul e learning, nilai estetika penggunaan Modul e learning berbasis Web

\section{Tabel 4. Hasil Validasi Media \\ Pembelajaran}

\begin{tabular}{|l|l|c|}
\hline No & \multicolumn{1}{|c|}{ Kriteria } & $\begin{array}{c}\text { Skor/ } \\
\text { Nilai }\end{array}$ \\
\hline 1 & $\begin{array}{l}\text { Kesesuaian media dan } \\
\text { tujuan }\end{array}$ & 5 \\
\hline 2 & $\begin{array}{l}\text { Kesesuaian media dengan } \\
\text { peserta didik }\end{array}$ & 4 \\
\hline 3 & $\begin{array}{l}\text { Kejelasan tampilan Modul } \\
\text { e learning berbasis Web }\end{array}$ & 4 \\
\hline 4 & $\begin{array}{l}\text { Nilai estetika Modul e } \\
\text { learning berbasis Web }\end{array}$ & 5 \\
\hline 5 & $\begin{array}{l}\text { Kualitas tampilan Modul e } \\
\text { learning berbasis Web }\end{array}$ & 4 \\
\hline 6 & $\begin{array}{l}\text { Kesesuaian Modul e } \\
\text { learning berbasis Web } \\
\text { dengan materi }\end{array}$ & 4 \\
\hline 7 & $\begin{array}{l}\text { Ketepatan Modul e } \\
\text { learning berbasis Web } \\
\text { dengan materi }\end{array}$ & 5 \\
\hline 8 & $\begin{array}{l}\text { Kelancaran dalam alur } \\
\text { cerita }\end{array}$ & 5 \\
\hline 9 & $\begin{array}{l}\text { Keseimbangan warna } \\
\text { Modul e learning berbasis } \\
\text { Web }\end{array}$ & $\begin{array}{l}\text { Kesatuan media wayang } \\
\text { dengan yang memainkan } \\
\text { wayang }\end{array}$ \\
\hline & 4 \\
\hline 10 & 44 \\
\hline
\end{tabular}

Berdasarkan penilaian dari ahli media pembelajaran sebagaimana tercantum dalam tabel di atas maka dapat dihitung persentase tingkat pencapaian Modul e learning berbasis Web yaitu sebagai berikut. 
Persentase =

$\frac{\mathrm{Z} \text { (jawaban } \mathrm{x} \text { bobot tiap pilihan) }}{\mathrm{n} \times \text { bobot tertinggi }} \times 100 \%$ $=44 /(10 \times 5) \times$

$100 \%$

$$
=44 / 500 x
$$

$100 \%$

$$
=88 \%
$$

Persentase pencapaian multimedia interaktif adalah $88 \%$. Ini berarti, Modul e learning berbasis Web berada pada kategori baik, sehingga Modul e learning berbasis Web tidak perlu direvisi.

\section{Deskripsi Hasil Tahap Implementasi}

Pada langkah implementasi ini dilakukan pada mahasiswa angkatan 2017 Program Studi Pendidikan Sejarah dan Sosiologi FPISH IKIP Budi Utomo Malang. Langkah implementasi diasosiasikan dengan penyelenggaraan kegiatan pembelajaran itu sendiri yaitu adanya penyampaian penyampaian materi pembelajaran dari dosen kepada mahasiswa. Implementasi ini bertujuan untuk mendapatkan masukan secara langsung dari mahasiswa yang telah mengikuti pembelajaran. Pembelajaran yang diterapkan adalah pembelajaran penerapan Modul e learning berbasis Web untuk meningkatkan karakter berbudiutama pada mahasiswa.

Implementasi dilakukan pada mahasiswa angkatan 2017 kelas A Program Studi Pendidikan Sejarah dan Sosiologi FPISH IKIP Budi Utomo Malang pada semester ganjil tahun ajaran 2017-2018 dengan jumlah mahasiswa 45. Implementasi pada penelitian ini dilakukan Selama 3 hari yaitu tanggal 22-24 Juni 2018 Pada tahap imlementasi ini dihasilkan data mengenai respon mahasiswa serta hasil belajar sesuai dengan hasil belajar yang didapatkan setelah melakukan pembelajaran dengan menggunakan Modul e learning berbasis Web setelah dilakukan taham implementasi maka akan dilakukan tahapan evaluasi dari penerapan Modul e learning berbasis Web

\section{Deskripsi Hasil Tahap Evaluasi}

Tahap evaluasi pada model ADDIE didefinisikan sebagai sebuah proses yang dilakukan untuk memberikan nilai terhadap program pembelajaran. Pada dasarnya, evaluasi dapat dilakukan sepanjang pelaksanaan kelima langkah model ADDIE.

Selain itu, evaluasi juga dapat dilakukan dengan cara melihat hasil belajar, respon mahasiswa. Deskripsi Hasil Implementasi penelitian ini dapat diuraikan sebagai berikut

1) Hasil Respon Kelompok Kecil

Respon mahasiswa
terhadap pelaksanaan
pengembangan media Modul
e learning berbasis Web
dengan pemberian angket
kepada mahasiswa setelah
melakukan pembelajaran
yaitu setelah Modul e
learning berbasis Web sudah
siap untuk diujikan kepada
kelompok kecil. Hasil respon


mahasiswa digunakan untuk melihat keefektifan dari Modul e learning berbasis Web yang telah dibuat oleh peneliti. Hasil perhitungan respon mahasiswa terhadap pembelajaran menggunakan media Modul e learning berbasis Web tersebut dapat dilihat pada perhitungan persentase berikut ini.

$$
\begin{aligned}
\text { Persentase } & =\mathrm{F}: \mathrm{N} \\
& =
\end{aligned}
$$$$
1148 \%: 14
$$$$
=82 \%
$$

Persentase pencapaian

Modul e learning berbasis Web adalah $82 \%$. Ini berarti Modul e learning berbasis Web berada pada kategori baik, sehingga Modul e learning berbasis Web tidak perlu direvisi.

2) Hasil Respon Kelompok Besar

Setelah mendapatkan respon dari kelompok kecil, selanjutnya dilakukan respon pada kelompok besar. Respon mahasiswa terhadap pelaksanaan pengembangan Modul e learning berbasis Web dengan pemberian angket kepada mahasiswa setelah melakukan pembelajaran yaitu setelah Modul e learning berbasis Web sudah siap untuk diujikan kepada kelompok besar. Hasil respon mahasiswa digunakan untuk melihat keefektifan dari Modul e learning berbasis Web yang telah dibuat oleh peneliti. Hasil perhitungan respon mahasiswa terhadap pembelajaran menggunakan Modul e learning berbasis Web tersebut dapat dilihat pada perhitungan persentase berikut ini.

$$
\begin{aligned}
\text { Persentase } & =\mathrm{F}: \mathrm{N} \\
& =3240 \%: 7 \\
& =81 \%
\end{aligned}
$$

Persentase Modul e learning berbasis Web adalah $81 \%$. Ini berarti, Modul e learning berbasis Web berada pada kategori baik, sehingga Modul e learning berbasis Web tidak perlu direvisi.

\section{KESIMPULAN DAN SARAN}

\section{Kesimpulan}

Berdasarkan landasan teori dan didukung oleh analisis data hasil uji instrumen penelitian, maka dapat di simpulkan sebagai berikut:

1. Modul e learning berbasis web sebagai bahan pembelajaran dalam mata kuliah Pendidikan Pancasila dan Kewarganegaraan dikategorikan baik akan tetapi perlu direvisi tentang kemudahan akses dan kemampuan bagi mahasiswa untuk menggunakan modul e learning berbasis web ini dalam pembelajaran Pendidikan Pancasila dan Kewarganegaraan. 
2. Modul e learning berbasis Web sebagai modul pembelajaran yang efektif, inovatif, kreatif dan menyenangkan dapat menumbuhkan rasa berbudiutama mahasiswa dalam matakuliah Pendidikan Pancasila dan Kewarganegaraan, dimana memerlukan analisis lebih lanjut akan penggunaan modul e leraning berbasis web dalam meningkatkan rasa berbudiutama mahasiswa.

\section{Saran}

Menyumbangkan pemikiran yang berkenaan dengan penelitian pengembangan modul e learning berbasis web pada pembelajaran Pendidikan Pancasila dan Kewarganegaraan maka disarankan hal-hal berikut:

1. Pendidik

$\begin{array}{lr}\text { Menggunakan } & \text { modul } \\ \text { pembelajaran yang } & \text { kreatif, } \\ \text { inovatif, efektif } & \text { dan } \\ \text { menyenengkan merupakan } & \text { kewajiban semua pendidik } \\ \text { untuk menggunakan } & \text { modul } \\ \text { yang mudah di akses } & \text { oleh } \\ \text { mahasiswa ran } & \text { dan } \\ \text { mengembangkan kemampuan } \\ \text { mahasiswa ralam } \\ \text { pengembangan diri } & \text { secara } \\ \text { ilmu pengetahuan } & \text { dan } \\ \text { teknologi sesuai dengan } \\ \text { tuntutan zaman. }\end{array}$

2. Mahasiswa

Pembelajaran akan menjadi hal yang menyenangkan melalui media pembelajaran yang kreatif, inovatif, efektif dan menyenengkan salah satunya dengan Modul e learning berbasis Web.

\section{DAFTAR PUSTAKA}

Adiputra, I. N. (2014). Pengembangan E- Modul pada Materi "Melakukan Instalasi Sistem Operasi Jaringan Berbasis GUI dan Text” untuk Siswa Kelas X Teknik Komputer dan Jaringan SMK Negeri 3 Singaraja. Karmapati.

Depdiknas. (2008). Panduan Pengembangan Bahan Ajar. Dirjen Dikdasmen Direktorat Pembinaan SMK.

Fausih, M., \& Danang, T. (2015). Pengembangan Media EModul Mata Pelajaran Produktif Pokok Bahasan "Instalasi Jaringan Lan (Local Area. Teknologi Pendidikan.

Gunadharma, A. (2011). Pengembangan Modul Elektronik Sebagai Sumber Belajar untuk Mata Kuliah Multimedia Design.

Diambil kembali dari SKRIPSI:

http://www.slideshare.net/ana ndagunadharma/ pengembangan-modulelektronik-sebagai- sumberbelajar-untuk-mata-kuliahmultimedia-design-anandagunadharma- 1215051060. 
Jonias, Hendri; $\quad$ (2014). Pengembangan Media Pembelajaran E-Module Terhadap Prestasi. Jurnal Pendidikan Teknik Elektro. Volume 03 Nomor 03.

Laili, J. (2011). Pengembangan Bahan Ajar Berbasis Web Materi Sistem Pernapasan Kelas XII IPA SMA ALRIFA'IE GondanglegiMalang. Skripsi Universitas Negeri Malang.

Moleong, Lexy. J. 2011. Metodologi Penelitian Kualitatif, Bandung : Remaja Rosdakarya.

Rusman. 2011. Model-Model Pembelajaran. Jakarta : Rajawali Pers.

Ryberg, T. (2010). Implementation of scientific approach for activities laboratory. Journal paedagogy. Vol 32.

Salsabila, R. P. (2013, Januari 14). Pengembangan Modul Elektronik Fisika Sebagai Media Instruksional Pokok Bahasan Hukum Newton Pada Pembelajaran Fisika Di SMA

(Http://Library.Unej.Ac.Id/Cl ient/En_Us/Defau 1t/Search/Asset/567?Dt=List)

Santyasa, I. W. (2009, Januari 1214). Metode Penelitian Pengembangan dan Teori Pengembangan Modul . Disajikan dalam Seminar Pelatihan Bagi Para Guru TK, SD, SMA, dan SMK.
Saputra, \& Agustin. (2012). Membangun Sistem Aplikasi E-Commerce dan SMS. Jakarta:

PT Elex Media

Komputindo.

Suarsana, I. M., \& Mahayukti, G. A. (2013). Pengembangan EModul Berorientasi Pemecahan Masalah Untuk Meningkatkan Keterampilan Berpikir Kritis Mahasiswa. Janapati.

Sudjana, Nana. 2012. Penilaian Hasil Proses Belajar Mengajar. Bandung: PT.Remaja Rosdikarya Offest.

Sudjana dan Ahmad Rifa'i. 2010. Media Pengajaran. Bandung: Sinar Baru Algensindo.

Sugiyono. 2010. Metode Penelitian Pendidikan (Pendekatan Kuantitatif, Kualitatif, dan $R \& D$ ). Bandung: Alfabeta.

Sunuyeko, Nurcholis. 2015. NilaiNilai Kebudi-utamaan. (Paper pada Penataran dan Lokakarya Bidang Penelitian bagi Dosen IKIP Budi Utomo Malang, tanggal 11-12 Februari 2015).

Yuhefizar. 2009. Cara Mudah Membangun Website Interaktif Menggunkan Content Mangement 
System Jomla CMS. Jakarta

: PT Gramedia 
Jurnal Edukasi, Volume ISSN. 2443-0455 